\title{
Pemberdayaan Berpikir Melalui Pertanyaan (PBMP) Pada Materi Klasifikasi Materi dan Perubahannya di SMPN 2 Tondano Via Dalam Jaringan (Daring)
}

\author{
Jilly Surachman ${ }^{*}$, Fransiska Harahap ${ }^{2}$ \\ 1,2 Jurusan Pendidikan IPA, FMIPA, Universitas Negeri Manado \\ *e-mail: surachmanj7@gmail.com
}

\begin{abstract}
Abstrak. Penelitian ini bertujuan untuk melihat perbedaan hasil belajar peserta didik pada pembelajaran IPA materi klasifikasi materi dan perubahannya dengan menggunakan Pemberdayaan Berpikir Melalui Pertanyaan (PBMP). Penelitian ini merupakan penelitian eksperimen semu menggunakan rancangan penelitian pretest posttest control group design. Populasi dalam penelitian ini adalah seluruh kelas VII di SMPN 2 Tondano dan sampel penelitian terdiri dari 2 kelas, yaitu kelas VIIC sebagai kelas eksperimen yang berjumlah 20 siswa dan kelas VIID sebagai kelas kontrol yang berjumlah 18 siswa. Pengambilan data dilakukan dengan memberikan pretest sebelum proses perlakuan dan posttest sesudah diberikan perlakuan. Data hasil penelitian yang diperoleh berupa selisih nilai rata-rata hasil pretest dan posttest pada kelas eksperimen adalah 46 sedangkan untuk kelas kontrol selisih nilai rata-rata hasil pretest dan posttest adalah 36,38. Setelah dilakukan uji statistik melalui uji-t, rata-rata hasil belajar yang diperoleh antara kelas kontrol dan kelas eksperimen yaitu thitung $=7,052>t_{\text {tabel }}=1,688$. Dengan demikian dapat disimpulkan bahwa terdapat pengaruh PBMP terhadap hasil belajar peserta didik pada pembelajaran IPA materi klasifikasi materi dan perubahannya di SMPN 2 Tondano kelas VII.
\end{abstract}

Kata kunci: pemberdayaan berpikir melalui pertanyaan, klasifikasi materi dan perubahannya

\begin{abstract}
This study aims to determine differences in learning outcomes student in the classification of science learning material and the changes using Thinking Empowering by Questions (TEQ). This research is a quasi-experimental study using a pretest posttest control group design. The population in this study were all class VII at SMPN 2 Tondano and the research sample consisted of 2 classes, namely class VIIC as an experimental class that could be used by 20 students and Class VIID as a control class totaling 18 students. The data was collected through a pretest before the research process was carried out and a posttest after the treatment. The research data obtained in the form of the difference in the average test results before and after the test in the experimental class was 46, while for the control class the average difference between the test results before and after the test was 36,38. Based on the statistical test using the t-test, the average learning outcome between the control class and the experimental class is $t_{\text {count }}=7,052>$ $t_{\text {table }}=1,688$. Therefore, it can be ignored that TEQ has an impact on student learning outcomes in the classification material of science learning material and its changes in SMPN 2 Tondano class VII.
\end{abstract}

Keywords: thinking empowering by questions, material classification and change

Diterima 06 November 2020 | Disetujui 26 November 2020 | Diterbitkan 31 Desember 2020

\section{PENDAHULUAN}

Pendidikan merupakan kebutuhan manusia yang penting untuk menyiapkan
Sumber Daya Manusia (SDM) bagi pembangunan bangsa dan negara. Berkembangnya suatu negara ditentukan 
oleh kualitas dan kuantitas dari komponen yang ada didalamnya yaitu masyarakat sebagai penentu masa depan dalam perkembangan ilmu pengetahuan dan teknologi. Sebagai salah satu sarana untuk mencerdaskan bangsa adalah diwujudkan dengan adanya pendidikan (Purwaningsih dalam Jamaludin, 2010). Ilmu Pengetahuan Alam (IPA) merupakan pengetahuan teoritis yang diperoleh atau disusun dengan cara yang khas atau khusus, yaitu dengan melakukan observasi, eksperimentasi, menyimpulkan, penyusunan teori, observasi, dan demikian seterusnya kait mengkait antara cara yang satu dan cara yang lain (Wulandari, 2017).

Dunia saat ini sedang marakmaraknya wabah coronavirus. Coronavirus itu sendiri adalah keluarga besar virus yang menyebabkan penyakit mulai dari gejala ringan sampai berat. Kebijakan pendidikan dalam masa darurat penyebaran COVID-19, proses belajar dilaksanakan di rumah melalui pembelajaran daring/jarak jauh dilaksanakan untuk memberikan pengalaman belajar yang bermakna bagi siswa.

Pembelajaran daring merupakan pemanfaatan jaringan internet dalam proses pembelajaran. Dengan pembelajaran daring siswa memiliki keleluasaan waktu belajar, dapat belajar kapanpun dan dimanapun. Siswa dapat berinteraksi dengan guru menggunakan beberapa aplikasi seperti google classroom, video converence, telepon atau live chat, zoom meeting maupun melalui WhatsApp group. Pembelajaran ini merupakan inovasi pendidikan untuk menjawab tantangan akan ketersediaan sumber belajar yang variatif (Kemdikbud.go.id., 2020).

Hasil observasi di SMPN 2 Tondano diperoleh informasi bahwa hasil belajar siswa pada pelajaran IPA masih kurang karena $70 \%$ nilai siswa berkisar antara 60-65, dan masih belum mencapai Kriteria Ketuntasan Minimum (KKM) yaitu 75 . Rendahnya nilai rata-rata IPA tersebut disebabkan oleh beberapa faktor diantaranya yaitu kurangnya pertanyaan-pertanyaan yang dapat membantu pemberdayaan berpikir pada proses pembelajaran. Hal ini dapat terlihat pada saat mengerjakan tugas yang diberikan guru, tidak semua siswa mengerjakan tugas, siswa tidak terbiasa dengan pertanyaan-pertanyaan sulit. Serta guru hanya mengembangkan beberapa keterampilan saja seperti keterampilan berkomunikasi dan keterampilan observasi. Keterampilan bertanya atau menjawab belum diupayakan dengan baik, siswa melakukan kegiatan diskusi dan tanya jawab.

Dalam kegiatan belajar IPA, pemahaman konsep siswa dipengaruhi oleh proses pembelajaran di kelas. Melalui PBMP siswa dibiasakan dengan pertanyaan-pertanyaan yang terus menerus tapi dengan pertanyaan yang terarah sehingga membuat siswa menjadi senang menjawab dan bisa dengan sendirinya membuat pertanyaan. Oleh karena itu, untuk mendorong potensi berpikir siswa, pelaksanaan pembelajaran dan evaluasinya harus dikelola secara terencana untuk memberdayakan keterampilan berpikir siswa. Penciptaan pertanyaan tersebut dapat dilakukan bersama-sama guru dan siswa. Guru harus mempersiapkan pertanyaan-pertanyaan, baik untuk dirinya sendiri maupun bagi siswanya. Guru harus menjadi katalisator dalam penciptaan pertanyaan-pertanyaan yang bersifat terbuka dan divergen akan menimbulkan respon dari siswa dan dapat menunjang kemampuan berpikir siswa. Pembelajaran IPA di sekolah tidak terlepas dari cara atau teknik pengolahan kelas dimana menekankan keteraturan proses pembelajaran dalam kelas. Ada banyak sekali model pembelajaran yang telah dikembangkan oleh para ahli untuk membantu para guru dalam pengolahan kelas, salah satu model yang dikembangkan adalah Pemberdayaan Berpikir Melalui Pertanyaan (PBMP). PBMP merupakan pola pembelajaran yang dilaksanakan dengan tidak ada proses pembelajaran yang berlangsung secara informatif, seluruhnya dilakukan melalui rangkaian atau jalinan pertanyaan yang telah 
dirancang secara tertulis dalam lembarlembar PBMP. Melalui pembelajaran dengan PBMP diharapkan dapat mengembangkan kemampuan berpikir kritis siswa yang merupakan salah satu ciri dari berkembangnya penalaran formal (Corebima, 2008).

\section{METODE PENELITIAN}

Penelitian ini dilaksanakan di kelas VII SMPN 2 Tondano dan waktu penelitian ini dilaksanakan pada bulan september semester ganjil tahun ajaran 2020/2021.

Metode penelitian yang digunakan dalam penelitian ini adalah metode eksperimen. Metode eksperimen dapat diartikan sebagai metode penelitian untuk mencari pengaruh perlakuan tertentu terhadap yang lain dalam kondisi yang terkendali (Sugiyono 2012).

Dalam mengumpulkan data pada penelitian ini, peneliti akan melakukan beberapa tahap prosedur penelitian sebagai berikut: (1) Menentukan populasi dan sampel penelitian. (2) Menentukan pokok bahasan yaitu klasifikasi materi dan perubahannya yang dilaksanaakan dalam bentuk daring. (3) Menyusun instrumen penelitian berupa tes dalam bentuk soal berpola PBMP. (4) Melaksanakan eksperimen dengan langkah-langkah sebagai berikut: (a) Menentukan kedua kelompok yaitu eksperimen dan kontrol, kelompok eksperimen menggunakan PBMP sebanyak satu kelas dan kelompok kontrol menggunakan metode pembelajaran konvensional sebanyak satu kelas. (b) Melaksanakan pretest pada hari yang sama pada dua kelas yaitu kelas eksperimen dan kelas kontrol. Soal pretest yang digunakan dalam penelitian ini berbentuk essay, tahapan tersebut bertujuan untuk mengetahui keadaan awal antara kedua kelas eksperimen dan kontrol. (c) Melakukan kegiatan belajar mengajar sesuai dengan RPP (dengan frekuensi pertemuan disesuaikan dengan silabus) pada kedua kelas eksperimen dan kontrol dengan alokasi waktu $2 \times 40$ menit. (d) Melaksanakan perlakuan kepada kelas eksperimen dengan menggunakan penggunaan PBMP dan kepada kelas kontrol menggunakan metode pembelajaran konvensional. (e) Melaksanakan posttest pada hari yang sama pada kedua kelas eksperimen dan kontrol. Soal posttest yang digunakan dalam penelitian ini berbentuk tes essay, tahapan ini bertujuan untuk melihat hasil akhir dari kedua kelas yaitu kelas eksperimen dan kelas kontrol.

Data hasil belajar siswa dikumpulkan dengan memberikan tes sebelum dan tes sesudah pembelajaran selesai pada materi IPA, sebelum tes tersebut diberikan terlebih dahulu diuji validitas dan reliabilitas.

Instrumen yang digunakan sebagai alat untuk memperoleh data yang diperlukan oleh peneliti dalam kegiatan penelitian yaitu observasi dan tes. Tes yang digunakan yaitu tes essay, sebelum instrumen hasil belajar tersebut digunakan terlebih dahulu sudah dilakukan uji validitas.

\section{HASIL DAN PEMBAHASAN Hasil Penelitian}

Penelitian ini menggunakan dua kelas yang telah diambil secara acak yaitu kelas VIIC yang berjumlah 20 siswa sebagai kelas eksperimen dan VIID dengan jumlah 18 siswa sebagai kelas kontrol. Kelas eksperimen merupakan kelas yang diberi perlakuan PBMP dan untuk kelas kontrol yang diberi perlakuan pembelajaran konvensional (ceramah) dengan materi klasifikasi materi dan perubahannya. Pembelajaran yang dilakukan juga merupakan pembelajaran daring dimana media yang digunakan yaitu Zoom Meeting dan WhatsApp. Setiap pertemuan yang dilakukan didasari dari RPP yang telah disediakan terlebih dahulu juga menggunakan lembar PBMP yang didalamnya adalah pertanyaan-pertanyaan yang sudah disediakan terlebih dahulu oleh peneliti. Hasil yang di peroleh menunjukan bahwa nilai rata-rata hasil posttest kelas eksperimen yang dicapai peserta didik adalah 77,5 lebih tinggi dari nilai ratarata posttest kelas kontrol yaitu 66,66 . 
Tabel 1. Statistik kelas eksperimen

\begin{tabular}{llll}
\hline Statistik & Pretest & Posttest & Selisih \\
\hline Rata-rata & 31,5 & 77,5 & 46 \\
$\begin{array}{l}\text { Skor } \\
\text { minimum }\end{array}$ & 20 & 60 & 20 \\
$\begin{array}{l}\text { Skor } \\
\text { maksimum }\end{array}$ & 50 & 95 & 65 \\
$\begin{array}{l}\text { Standar } \\
\text { deviasi }\end{array}$ & 10,52 & 11,41 & 10,20 \\
Varians & 110,78 & 130,26 & 104,21 \\
\hline
\end{tabular}

Tabel 2. Statistik kelas kontrol

\begin{tabular}{llll}
\hline Statistik & Pretest & Posttest & Selisih \\
\hline $\begin{array}{l}\text { Rata-rata } \\
\text { Skor }\end{array}$ & 30,27 & 66,66 & 36,38 \\
$\begin{array}{l}\text { minimum } \\
\begin{array}{l}\text { Skor } \\
\text { maksimum }\end{array}\end{array}$ & 10 & 50 & 15 \\
$\begin{array}{l}\text { Standar } \\
\text { deviasi }\end{array}$ & 13,55 & 11,75 & 11,48 \\
Varians & 183,74 & 138,23 & 131,78 \\
\hline
\end{tabular}

Berdasarkan data hasil penelitian yang diperoleh dari hasil belajar PBMP pada kelas VIIC sebagai kelas eksperimen dan kelas VIID sebagai kelas kontrol, menunjukan bahwa kedua sampel berdistribusi normal dan perbandingan kemampuan pada kelas eksperimen dan kelas kontrol adalah Homogen.

Dari data uji t dapat dilihat bahwa nilai thitung $=7,052$ lebih besar dari nilai $t_{\text {tabel }}=1,688$ pada taraf signifikan $\alpha=0,05$. Berdasarkan kriteria pengujian hipotesis, dimana apabila thitung lebih kecil atau sama dengan $t_{\text {tabel }}\left(t_{\text {hitung }} \leq t_{\text {tabel }}\right)$, maka $\mathrm{H}_{0}$ diterima dan $\mathrm{H}_{\mathrm{a}}$ ditolak. Oleh karena data yang dianalisis diperoleh nilai thitung lebih besar dari nilai $t_{\text {tabel }}\left(t_{\text {hitung }}>t_{\text {tabel }}\right)$ maka $\mathrm{H}_{0}$ ditolak dan $\mathrm{H}_{\mathrm{a}}$ diterima, sehingga dapat disimpulkan bahwa terdapat perbedaan yang signifikan dari hasil belajar siswa yang menggunakan pola PBMP dan hasil belajar siswa yang menggunakan pembelajaran konvensional. Hasil belajar pada kelas eksperimen memiliki rata-rata yang lebih tinggi yaitu 46 dibandingkan dengan rata-rata hasil belajar pada kelas kontrol yaitu 36,38 .

\section{Pembahasan}

Perbedaan hasil belajar antara kelas yang menggunakan PBMP dan yang tidak yaitu kelas yang menggunakan pembelajaran PBMP efektif dalam meningkatkan hasil belajar siswa. Hal ini dapat dilihat dari hasil belajar PBMP lebih tinggi dari rata-rata hasil belajar siswa dengan menggunakan pembelajaran konvensional. Hasil penelitian ini sejalan dengan penelitian Yunarti (2009), yang menjelaskan bahwa pertanyaan yang dapat menimbulkan pembaca yang kritis yaitu: pertanyaan yang menyelidiki informasi dan pengalaman, pertanyaan yang yang meminta alasan dan bukti, pertanyaan yang mengarahkan siswa untuk memeriksa penafsiran dan kesimpulan dan mengejar kesimpulan dan mengejar pengalaman. Lembar PBMP semakin terlihat dapat meningkatkan kemampuan berpikir ketika dalam proses diskusi baik pada tahap renungkan, pikirkan maupun evaluasi yang mampu memberdayakan dan mengembangkan penalaran siswa (Dahar, 2011).

PBMP terbukti berpengaruh terhadap motivasi siswa. Hal ini disebabkan pembelajaran PBMP menuntut siswa berperan aktif sehingga siswa termotivasi. Pada tahap lakukan siswa mengikuti intruksi pada lembar PBMP dan berusaha melakukan pengamatan dengan benar. Siswa yang belajar dengan berbagai masalah atau pertanyaan akan memicu rasa ingin tahu siswa. Lembar siswa yang berisi jalinan pertanyaan harus dicermati dan ditanggapi oleh siswa. Siswa harus mencermati tiap poin pertanyaan, karena pertanyaan-pertanyaan pada lembar saling berkaitan. Adanya pertanyaan yang disusun dengan baik dan logis, akan mudah memahami selusuh isi dari lembar siswa yang diberikan.

Sebuah pertanyaan dapat menumbuhkan rasa ingin tahu dan merangsang aktivitas mental siswa. Rasa ingin tahu yang dimiliki siswa dapat berpengaruh positif. Siswa akan terus menambah pengetahuannya terutama hal-hal yang ada dalam kehidupan seharihari (Wilen dalam Yunarti, 2009).

Pembelajaran dengan PBMP disamping siswa aktif menjawab pertanyaan-pertanyaan dalam pola PBMP, ternyata juga memacu timbulnya 
pertanyaan-pertanyaan

(Rosyidah,

Zubaidah \& Mahanal, 2015).

Siswa termotivasi belajar bila pelajaran itu bermaksa baginya, karena itu dianjurkan agar pelajaran yang dilakukan bermakna bagi siswa, hal ini berhubungan dengan semakin berkembangnya penalaran siswa (Suyud, 2006).

Hasil analisis diatas juga didukung dengan hasil penemuan Corebima (2008), yang menyatakan bahwa dengan penggunaan pola PBMP akan memacu siswa untuk terus berpikir dan menyusun pengetahuan dengan memaknai setiap proses dan pada akhirnya dapat membentuk suatu konsep utuh melalui usahanya sendiri. Hal tersebut sesuai dengan pembelajaran kontekstual kontruktifisme.

Usaha memecahkan pertanyaan dengan frekuensi sesering mungkin dapat melatih daya pikir yang dimiliki siswa, daya pikir yang telah terbentuk selanjutnya dapat dioptimalkan untuk memecahkan pertanyaan yang dihadapi oleh siswa. Siswa dilatih untuk memperoleh dan memahami pengetahuan yang dibutuhkan secara langsung, sehingga apa yang dipelajari lebih bermakna bagi dirinya (Fauziyah, 2018).

\section{KESIMPULAN}

Berdasarkan hasil penelitian dan pembahasan, disimpulkan bahwa pembelajaran menggunakan pola PBMP berpengaruh terhadap hasil belajar peserta didik di SMPN 2 Tondano kelas VII.

\section{DAFTAR PUSTAKA}

Corebima. A. D. (2008). Pemberdayaan Berpikir Melalui Pertanyaan Penelitian Tindakan Kelas Strategi Pembelajaran Assesmen. Makalah. Universitas Negeri Malang

Dahar, R. W. (2011). Teori-Teori Belajar dan Pembelajaran. Jakarta:Erlangga

Fauziyah, L. (2018). Pembelajaran IPA Model Pola Pemberdayaan Berpikir Melalui Pertanyaan (PBMP) dalam Pembelajaran Kooperatif Team Game Tournament (TGT) terhadap Motivasi dan Hasil Belajar Siswa Kelas IV MIN
2 Kota Malang. Disertasi. Universitas Islam Negeri Maulana Malik Ibrahim.

Jamaluddin, J. (2010). Pemberdayaan Berpikir Melalui Pertanyaan dan Strategi Kooperatif Untuk Meningkatkan Keterampilan Metakognitif Siswa. Jurnal Ilmu Pendidikan Universitas Negeri Malang, 16(3), 110604.

Kemdikbud.go.id. (2020, Maret 03). Kemendikbud Imbau Pendidik Hadirkan Belajar Menyenangkan Bagi Daerah yang Terapkan Belajar di Rumah. Diakses pada 10 Desember 2020, dari https://www.kemdikbud.go.id/main/blog /2020/03/kemendikbud-imbaupendidik-hadirkan-belajarmenyenangkan-bagi-daerah-yangterapkan-belajar-di-rumah

Rosyidah, Z., Zubaidah, S., \& Mahanal, S. (2015). Pengaruh Pola Pemberdayaan Berpikir Melalui Pertanyaan dalam Pembelajaran Team Game Tournament terhadap Kemampuan Kognitif, Sikap IPA dan Kesadaran Metakognitif Siswa. Jurnal Pendidikan Sains, 3(1), 42-48.

Sugiyono. (2012). Metode Penelitian Kuantitatif Kualitatif dan R\&D. Bandung: Alfabeta.

Suyud. (2006). Hubungan Sikap Profesional Pengelola Perpustakaan, Motivasi Guru dan Sarana Prasarana Perpustakaan dengan Motivasi Belajar Siswa di Perpustakaan Madrasah Tsanawiyah Swasta Sekelompok Kerja Madrasah Tsanawiyah Negeri Pajarakan Probolinggo. Malang

Wulandari, R. (2017). Berpikir Ilmiah Siswa dalam Pembelajaran IPA Untuk Meningkatkan Literasi Sains. SEJ (Science Education Journal), 1(1), 2935.

Yunarti, T. (2009, December). Fungsi dan Pentingnya Pertanyaan dalam Pembelajaran. In Makalah Prosiding disampaikan pada Seminar Nasional Matematika Jurusan Pendidikan Matematika FMIPA UNY (Vol. 5). 